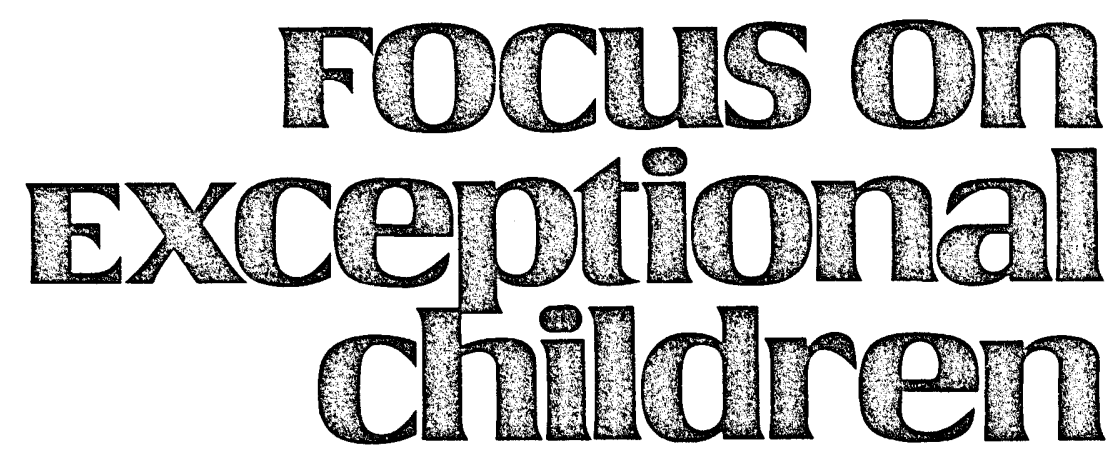

\title{
Computer Applications in Instruction
}

Melvyn I. Semmel and Joan A. Lieber

Recent national surveys have chronicled the progress of microcomputer diffusion and adoption in our nation's schools (Becker, 1983; 1985). In 1983 the majority of elementary schools in the United States had at least one microcomputer, but few had as many as five. Two years later most of the schools reported having five or more computers, with over 7,500 housing more than 15 (Becker, 1985).

In many instances introduction of computers in the schools has been the result of marketing strategies designed to manufacture teacher "excitement" by broadly advertising largely undocumented potential effects of microcomputer applications (M. Semmel, Cosden, D. Semmel, \& Kelemen, 1984). The consequence has been a rate of technology adoption in our nation's schools that clearly exceeds the accrual of empirical evidence on the impact of the innovation. In fact, a general conceptualization is lacking to assist educators in prioritizing the importance of empirical questions that require study. Both researchers and practitioners are becoming aware of the complexities when attempting to operationally define the simple effects of microcomputer applications on various learner populations in various educational environments (M. Semmel, D. Semmel, Cosden, Gerber, \& Goldman, 1983).

\section{TRADITIONAL INVESTIGATIONS OF MICROCOMPUTER EFFECTIVENESS}

Initial empirical efforts to determine the effects of microcomputer applications emulated prior efforts associated with determining the impact of computer-assisted instruction (CAI) delivered through mainframe computers (Edwards, Norton, Taylor, Weiss, Dusseldorp, 1975; Vinsonhaler \& Bass, 1972). Earlier researchers contrasted the benefits of CAI with standard teacher-based instructional delivery modes. Classically, dependent variables focused on differentiating relative pupil academic gains, the relative efficiency of learning, and cost effectiveness of CAI applications for regular education students. Hence, CAI was viewed as a simple intervention variable to be compared with standard educational treatments. Investigations of computer effects with mildly handicapped students generally have followed the conceptual patterns and designs alluded to above.

In a recent review of this literature, the present authors (Lieber \& Semmel, 1985) found that studies comparing CAI to instruction delivered by a teacher revealed equivocal results. For example, one study found CAI to be superior (Watkins \& Webb, 1981), and two found no difference (Carman \& Kosberg, 1982; McDermott \& Watkins, 1983). Two studies that compared a task on the microcomputer to the same task using paper and pencil had similarly inconsistent findings. One found that the paper-and-pencil task led to better performance (Varnhagen \& Gerber, 1984), and the other found generally no difference but more work accomplished with the microcomputer (Kleiman, Humphery,

Melvyn Semmel and Joan Lieber are faculty members of the Department of Education, University of California, Santa Barbara, where he is a Professor and she is a Postdoctoral Researcher. 
\& Lindsay, 1983).

A number of workers in the field have challenged the fruitfulness of simple comparative research in determining the effectiveness of microcomputer instruction. Clark (1983), for example, argued that microcomputers are the "vehicles that deliver instruction but [they] do not influence student achievement any more than the truck that delivers our groceries causes changes in our nutrition" (p.445). He suggested that the positive outcomes attributed to learning from media are as likely to be the effects of novelty, or the effects of the different instructional methods and curriculum content used by the software and the comparison teacher.

Given the equivocal results of the comparative treatment studies and the conceptual criticisms of viewing CAI as a composite instructional variable, to continue to design research in special education that compares generically defined traditional instruction with poorly specified CAI would appear inadvisible. More pertinent, the widespread adoption of computers in classrooms demands data-based answers to focused questions that assure building a validated network of interrelated knowledge with direct implications for optimizing the educational effects of computer applications with handicapped pupils. We must focus on how computers are allocated to various educational environments and how

\section{Focus on
Exceptional
children}

FOCUS ON EXCEPTIONAL CHILDREN (ISSN0015-5IIX) (USPS 203-360) is published monthly except June, July, and August as a service to teachers, special educators, curriculum specialists, administrators, and those concerned with the special education of exceptional children. This journal is abstracted and indexed in Exceptional Child Education Resources, and is also available in microform from Xerox University Microfilm. Ann Arbor, Michigan. Subscription rates, $\$ 18.00$ per year. Copyright $\odot 1986$, Love Publishing Company. All rights reserved. Reproduction in whole or part without written permission is prohibited. Printed in the United States of America. Second class postage is paid at Denver, Colorado.

POSTMASTER: Send address changes to:

Love Publishing Company

Executive and Editorial Office

1777 South Bellaire Street

Denver, Colorado 80222

Telephone (303) 757-2579

EDITORIAL BOARD
Edward L. Meyen

University of Kansas

Richard J. Whelan

University of Kansas Medical Center they are configured through instructional delivery systems. We must understand the role of these variables in determining how mildly handicapped pupils access, use, and benefit from technology applications. Hence, a conceptual modelone that guides the study of both distal and the more proximal factors associated with achieving instructional objectivesclearly is needed to guide the study of these complex relationships. Ultimately, research on microcomputer applications with mildly handicapped pupils must lead to validated specification of the molar and molecular service delivery variables necessary for maximizing desired academic and social outcomes for learners.

\section{A MODEL FOR STUDYING MICROCOMPUTER EFFECTS ON MILDLY HANDICAPPED LEARNERS}

\section{Researchers at the University of California, Santa Barbara} (M. Semmel et al., 1983) recently developed a comprehensive path model to guide a four-year federally funded research program-Project TEECh (Technology Effectiveness with Exceptional Children)-designed to study the effects of microcomputer technology in special education contexts. The path model (see Figure 1) shows the hypothesized distal and proximal causal chains involved in the allocation, delivery, and use of technology by pupils. Among the links that are most proximal to educational outcomes are: (1) the attributes of the learner and his or her peers, and (2) the specific characteristics of the instructional setting, which combine to form the MicroEducational Environment (MEE).

As depicted in the model, the MEE is defined by a number of contextual variables including the technological configuration and architecture of the hardware, instructional content of the software, teacher effectiveness, administrative arrangement (e.g., resource room, special day class), how children are grouped for instruction, and the cognitive and personality characteristics of the target student and his or her peers. Thus, the effects of microcomputer instruction are hypothesized to result from a complex interaction of mediating variables. Only through a systematic examination of these variables can we specify the conditions under which particular microcomputer effects can be expected for various populations of elementary school users.

In the remainder of this article, we utilize this conceptualization and begin to specify selected MEEs for mildly handicapped and nonhandicapped elementary school pupils. We begin with a review of survey data describing how microcomputers currently are being used in classrooms that serve mildly handicapped students. The review brings us to a discussion of important experimental investigations that logically followed from the findings of the survey studies. These studies, which were related primarily to mathematics content, systematically varied the facets of MEEs toward determining specific instructional effects on mildly hand- 


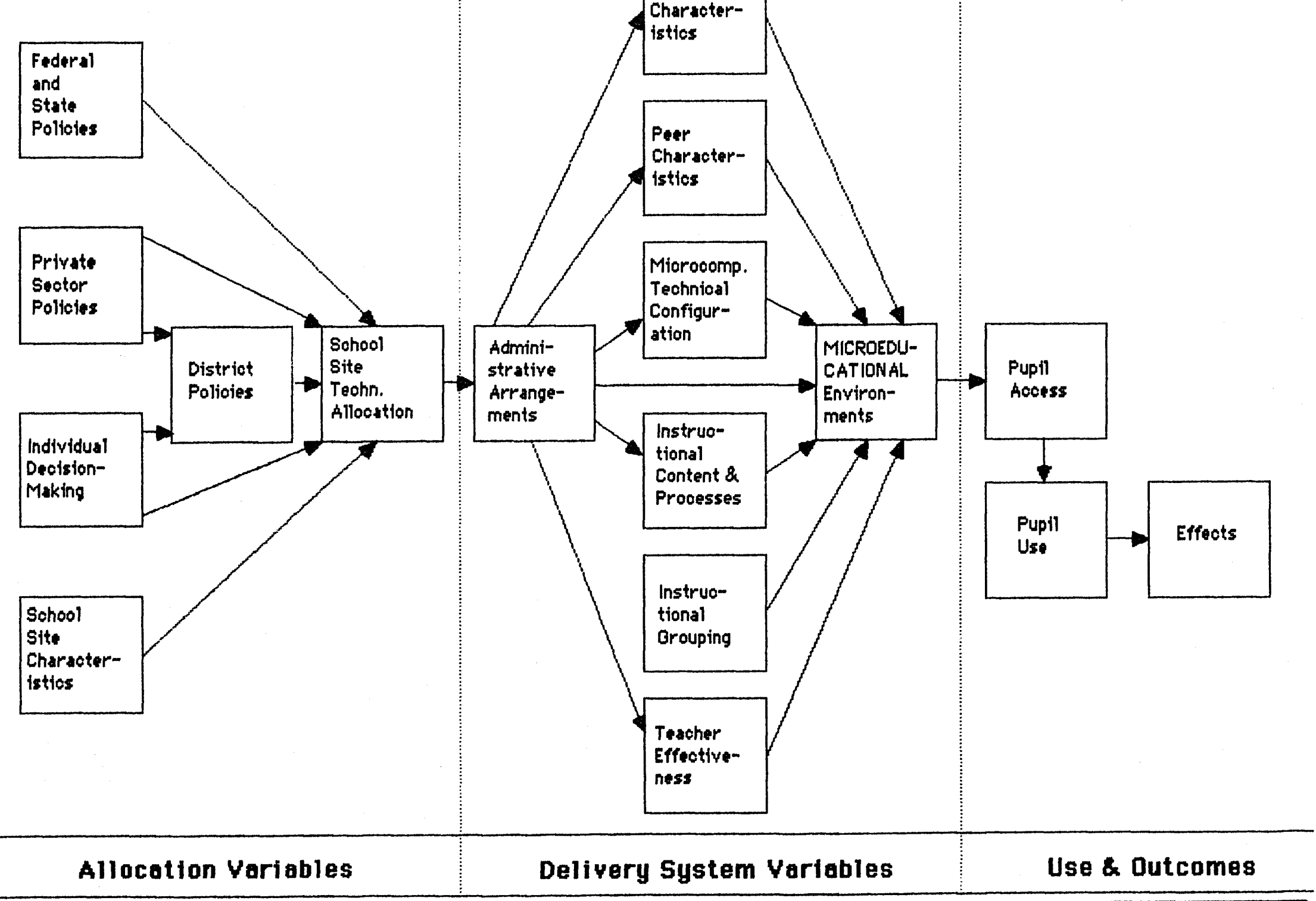

FIGURE 1 
icapped elementary school pupils. We conclude with a number of inferences, drawn from the empirical work reviewed, that may assist teachers in maximizing specific academic and social outcomes for mildly handicapped students through microcomputer applications.

\section{INSTRUCTIONAL USES OF MICROCOMPUTERS IN ELEMENTARY SCHOOLS}

Microcomputer technology has been described as revolutionary, with the capability of transforming the classroom into an environment in which students create their own businesses, navigate the Oregon Trail, watch a volcano erupt, and determine how pollution affects organisms in a pond (Lesgold, 1983). Although software packages have been created to simulate those environments, in reality the majority of microcomputer-based instruction delivered to both handicapped and nonhandicapped learners in classrooms is more conventional.

\section{Use with Normally Achieving Children}

In a survey reported by Becker (1985), a majority of the teachers surveyed indicated that computers in their schools were used primarily to deliver instruction in basic skills. In addition, over half of the elementary teachers believed this application to be the most promising use of microcomputers. In a more limited study, Littlejohn, Ross, and Gump (1984) found that microcomputers were used "almost exclusively as a tutor for drill and practice activity" (p. 5). Additionally, these investigators reported that teachers maximized the number of students who had access to the computer by scheduling limited per-pupil time on the computer and by having pairs of students work together on the computer.

Littlejohn et al. inferred a relationship between the decision to use drill-and-practice programs and the teachers' strategy to maximize student access to the computer. Other reasons for limiting the computer to drill-and-practice use were derived from the direct observation portion of the study and through further teacher questioning. Littlejohn et al. indicated that teacher supervision of the microcomputer area was limited and that the teachers viewed the microcomputer as something they needed to "squeeze into their already full schedule" (p. 5). Certainly teachers with little time to devote to the computer have less difficulty using it to deliver drilland-practice tasks than using it to teach programming or word processing. Drill-and-practice programs also can be utilized by teachers with little computer knowledge of their own.

\section{Use with Mildly Handicapped Learners}

A survey designed specifically to examine microcomputer access and use patterns with mildly handicapped learners was administered by Project TEECh researchers (D. Semmel, Goldman, Gerber, Cosden, \& M. Semmel, 1985), who questioned special day class teachers, resource room teachers, and regular education teachers with mildly handicapped students mainstreamed into their classrooms. This survey sampled over 200 teachers in a four-county region in Southern and Central California. Additional descriptions of mildly handicapped learners' use of microcomputers were generated through an observational study (Cosden, Gerber, D. Semmel, Goldman, \& M. Semmel, in press) conducted in 90 special education and regular education classrooms.

\section{Instructional Use of Software}

In findings similar to those from regular education surveys, Semmel et al. found that $96 \%$ of the teachers used microcomputers at least in part for drill and practice. Fewer teachers used the computer for other instructional purposes. Approximately two-thirds of the teachers used microcomputers for games or for instruction in computer use, $40 \%$ for programming and tutorials, and $25 \%$ for writing and simulation activities. These data represent combined percentages over all teachers. Teacher groups, however, varied considerably in some instructional purposes. A substantially larger portion of regular education teachers used the microcomputer for instruction in computer use, programming, tutorials, and simulations. Special day class teachers used games more frequently than did either resource room or regular education teachers.

These findings were confirmed in the observational study (Cosden et al., in press). Most of the software programs used across instructional settings had a drill-and-practice format, and the subject area observed most frequently was mathematics. Although the subject area and instructional format of software programs observed did not vary widely, the actual programs used varied considerably. In fact, the 205 study participants were observed using over 130 different software programs.

\section{Grouping for Instruction}

D. Semmel et al. (1985) indicated that in delivering computer instruction teachers primarily used a small-group configuration (86\%). The next most frequently used configuration was individual, as reported by $70 \%$ of the respondents. Administrative arrangements, however, differed. Resource room teachers preferred to assign children to work individually in preference to small groups (89\% compared to $81 \%$ ), whereas regular class teachers used a small-group configuration much more frequently than an individual configuration (95\% compared to $67 \%$ ).

The pattern of grouping was cross-validated in direct observation (Cosden et al., in press). The majority of both 
handicapped and nonhandicapped students in the mainstream worked in small, homogeneous ability groups $(55 \%$ and $59 \%$, respectively), but a significant number also worked individually (34\% for handicapped; $35 \%$ for nonhandicapped). In resource rooms and special day classes patterns were different. In these settings mildly handicapped students worked at the computer primarily by themselves $(81 \%$ and $58 \%$, respectively). D. Semmel et al. (1985) suggested that children are assigned in groups to maximize access to a limited number of microcomputers, and individual assignments frequently relate to the fact that many software programs are designed for children working alone.

\section{Purposes for Which Teachers Use Microcomputers}

Both regular education teachers and special education teachers reported that they used microcomputers predominantly to supplement the current lesson. This substantiates the hypothesis that teachers use drill programs frequently under the assumption that pupils have learned the skills presented in the program and need practice to achieve automaticity. For special education teachers, individual remediation was the second most frequently cited purpose for microcomputer applications; it was cited last for regular education teachers. Special education teachers may use the individual configuration more than their regular education counterparts since the former are trained to prefer "individualized instruction." Of particular interest was that the special education teachers listed recreation as the third purpose for which they used microcomputers, and teaching new skills as their lowest preference. Regular education teachers ranked these purposes second and third, respectively.

In summary, both the survey data and actual observation clearly show that the overwhelming use of computers in the classroom is for drill and practice. Teacher reliance on this particular instructional application of software may be a result of the nature and limited duration of the programs, which allow more students to have access to the computer. In addition, since the software is designed to provide practice on information previously presented, relatively little teacher supervision is demanded. Hence, teachers are free to work with other children. Drill-and-practice programs are also compatible with other, more personal, agenda that teachers may have. Computers represent a new technology, and some teachers are unfamiliar and even uncomfortable with them. Drill-and-practice software programs allow adults to utilize the technology in an undemanding way that requires little computer knowledge.

Teachers may have managerial or organizational reasons, unrelated to instructional objectives, for assigning mildly handicapped children to the computer for drill-and-practice work. The Project TEECh researchers observed that mildly handicapped learners generally attend to computer-presented stimuli but may demonstrate relatively high error rates on drill-and-practice programs that are accompanied by very low rates of teacher monitoring. The primary instructional motivation for assigning mildly handicapped learners to microcomputer-delivered drill-and-practice tasks must be to build high rates of correct responding to already learned material (automaticity). Children who have not yet learned the basic facts that they are assigned to practice on a drill program will in effect be subjected to a relatively poor basic skills teaching program.

\section{MICROEDUCATIONAL ENVIRONMENTS: INSTRUCTIONAL FORMATS}

\section{Drill-and-Practice Microcomputer Programs: Pros and Cons}

Although drill-and-practice programs are the most frequently used software in schools, they also are the most criticized. Hofmeister (1984) suggested that this criticism may be justified because of the large volume of poorly written products developed by beginning programmers. These programmers write drill-and-practice routines because they are short and do not require sophisticated programming skills. The result is software that "confuse[s] the naive user, anger[s] the sophisticated user, and embarass[es] the authors as they become more skilled in CAI development" (Hofmeister, 1984, p. 9).

Other criticisms relate to the limited instructional value of drill and practice. Russell (1983) suggested that computers should motivate by providing instructionally compelling content. She argued that drill and practice programs offer a "dizzying display of speed, color, motion, and sound" (p. 38), which are highly motivating but are "devoid of learning potential" (p. 38). Turkel and Podell (1984) object to the stimulus-response nature of drill-and-practice software in which students are passive recipients rather than active initiators of learning. Similar objections are raised by Garson (1983), who adds that workbooks provide an alternative to computerized drill and practice that is cheaper and allows students a more active role in the process of learning. These objections to drill-and-practice learning represent the position of proponents who advocate the computer for exploratory, discovery-based, inductive learning (Lepper, 1985).

In contrast to critics of drill-and-practice software, it also has strong supporters (Gagne, 1983; Lesgold, 1983), particularly those who advocate its use with mildly handicapped students (Hofmeister, 1984; Torgesen, 1984) who typically are deficient in basic reading and math skills. Torgesen (1984) argued that handicapped children do poorly in reading and math because they may have failed to master the com- 
ponent processes required to understand text and solve complex math problems. These component processes are mastered only when children are both accurate and rapid in their retrieval. Making retrieval automatic requires extensive practice for which drill-and-practice programs delivered through a computer are ideally suited. Students are highly motivated to work at computers (Lepper, 1985), and computers have the capacity to monitor both the speed and accuracy of students' responses (Torgesen, 1984). Computers are beneficial, therefore, for encouraging adequate amounts of practice and for allowing teachers to know when practice has been sufficient.

\section{Game Formats in Drill-and-Practice Software}

Even among those who advocate drill-and-practice programs, they disagree as to whether drill should be presented in an unadorned fashion, like a mechanized flash card, or be embedded within the structure of a game. Game elements are incorporated into drill-and-practice software for their motivational qualities (Chaffin, Maxwell, \& Thompson, 1982; Malone, 1981). These motivational elements, described by Malone (1981), include an explicit goal, score kept by the computer, audio effects, randomization of elements, and a relationship between speed and outcomes. Project TEECh researchers (Christensen \& Gerber, 1986), however, have suggested that the very attributes used to enhance motivation may compete for the attention necessary to learn the task, which, in turn, limits automaticity. Sufficient attention to task seems particularly critical for mildly handicapped learners, who typically are defined as deficient in this area (Hallahan \& Reeves, 1980).

\section{Comparison of Two Drill-and-Practice Programs}

Christensen and Gerber (1986) addressed the issue of software design by comparing progress toward automatically in single-digit addition for learning disabled and nondisabled children using two different drill-and-practice programs. One program, Alien Addition (Chaffin \& Maxwell, 1982), presents single-digit addition drill in a game format. The researchers indicated that Alien Addition contains many of Malone's (1981) criteria for game preference but added that it also contains distracting visual and auditory elements. Also, game playing strategies that must be adopted to play the game well divert attention from identification of correct answers to problems.

The comparison program, entitled Plain Vanilla, was developed by the TEECh group (Christensen, 1985) and contains only the essential aspects of the instructional task. Plain Vanilla presents a single addition problem in horizontal form (e.g., $3+4=$ ). The learner's response to the problem is followed by a corrective feedback statement (e.g., "That is correct."), which flashes on the screen with an accompanying tone.

The research examined comparative performance of 30 learning disabled and 30 nonlearning disabled students who had not yet developed automaticity in single-digit addition facts. These learners were assigned randomly to training using the Alien Addition or Plain Vanilla program. Dependent measures included: (a) number of correct responses on a timed written test, (b) response latency on an oral addition test (with problems presented by the computer), and (c) response latency on a keyboard addition test.

Christensen and Gerber (1986) found that under all three response conditions learning disabled children trained on Plain Vanilla performed significantly better than learning disabled children trained on Alien Addition. One explanation for the relatively poor performance of learning disabled children using Alien Addition could be their inability to selectively attend to the drill rather than to the program's game aspects. On the other hand, software design characteristics appeared to have relatively little differential effect on the performance of nonhandicapped learners.

The investigators also addressed the comparative motivational attributes of the two programs. Chaffin and Maxwell (1982), in their design of Alien Addition, linked the arcadelike characteristics of the program to student involvement and persistence. In turn, Christensen and Gerber operationalized these attributes (i.e., student involvement and persistence) as amount of practice (or correct problems accomplished) for each program. Results indicated that students working on Plain Vanilla practiced significantly more problems over the total number of computer sessions than did students working on Alien Addition. The researchers concluded that if we accept Chaffin and Maxwell's definition of motivation as a willingness to perform the instructional task, Plain Vanilla was a more motivating program than Alien Addition for the students in this study.

In considering the value of drill-and-practice computer programs, it is important to note that students made substantial gains in automaticity. Over the course of the study, pupils were at the computer for only 78 minutes, yet averaged $22 \%$ more responses on the written posttest and reduced their latencies by $13 \%$ on the oral posttest. As stated by the authors:

Typically, teachers in the school district in which the study was conducted allocated forty minutes for math instruction each day. It appears that computerized drill and practice provides an extremely efficient form of instruction. Over the course of the study, students practiced addition facts for what amounts to only two days of math instruction and yet they made outstanding progress in acquiring proficiency in the skill. (Christensen \& Gerber, 1986, p. 109)

Clearly, if teachers have defined the development of automaticity as a goal for their students, computerized drill 
and practice is an efficient and effective way to provide that practice. The Project TEECh researchers caution, however, that drill and practice must be integrated into the curriculum and used at the appropriate time. The contrasted programs did not aid children in a conceptual understanding of addition, nor did the programs assist them in generating the correct answer if that answer was not known. Similar nonempirically-based caveats were mentioned by Hofmeister (1984), who stated that drill-and-practice programs are most effectively used after concepts related to the skill have been taught, and prior to application of those skills to higher levels in the curriculum hierarchy.

\section{MICROEDUCATIONAL ENVIRONMENTS: GROUPING FOR INSTRUCTION}

In studies that surveyed both regular and special education teachers (Littlejohn et al., 1984; D. Semmel et al., 1985), microcomputer instruction was most often delivered to children working in small groups. Everhart, McCarthy, and Simpson (1985), another Project TEECh team, utilized ethnographic data and corroborated the survey finding that teachers may use different configurations for managerial or organizational rather than instructional reasons. But there is strong reason to believe that group instruction may be associated with important cognitive and social objectives for mildly handicapped children.

\section{Cognitive Benefits in Cooperative Learning Groups}

Evidence for a relationship between working in groups and academic growth for mildly handicapped learners comes primarily from research in the area of cooperative learning (e.g., Armstrong, Johnson, \& Balow, 1981; Cosden, Pearl, \& Bryan, 1985; Madden \& Slavin, 1983; Slavin, Madden, \& Leavey, 1984; Smith, Johnson, \& Johnson, 1982). These studies compared academic outcomes for children who learned individually versus children who learned in groups. Characteristics of learning in a group included both task interdependence and group reward. Results showed generally that children performed better academically when they worked in cooperative groups.

Several researchers have proposed models to account for superior learning in groups. Slavin (1983) suggested that cooperative learning is successful in producing gains in student achievement when specific group rewards are given based on the individual learning of group members. Specific group rewards increase the probability that students will help one another. Slavin believes that help will focus on explaining rather than providing an answer, because if all group members do not understand the material, the group will fail. Motivation to ensure that all group members learn therefore is provided by the desire to achieve the reward.
Other mechanisms to account for superior learning in groups are provided by Webb (1982). She has suggested that the verbal interactions occurring within groups lead to "cognitive restructuring" and a superior understanding of the material to be learned, by both the student who is explaining the material and the student who is the recipient of the explanation. In addition, evidence supports the view that conceptual conflict arises during discussion, causing students to examine their own understanding of information and to seek resolution of conflicting viewpoints (Dickson \& Vereen, 1983).

\section{Social Benefits of Cooperative Learning Groups}

Cooperative learning groups initially were used with mildy handicapped learners to facilitate positive child-child social interactions and to increase opportunities for social learning. Cooperative groups also have been shown to be an effective strategy for improving social acceptance of handicapped learners in recreational activities (Johnson, Rynders, Johnson, Schmidt, \& Haider, 1979; Martino \& Johnson, 1979) and in mainstreamed classrooms (Ballard, Corman, Gottlieb, \& Kaufman, 1977; Cooper, Johnson, Johnson, \& Wilderson, 1980; Johnson \& Johnson, 1982; Slavin et al., 1984).

Several conceptual models attempt to explain the positive interpersonal relationships that develop within cooperative groups (e.g., Johnson \& Johnson, 1980; Slavin, 1983). In these models the group task structure and group reward are hypothesized to lead to increased contact and to a sense of similarity among group members. In addition, an individual's ability to complete a task and receive a reward may be facilitated through the efforts of other group members. These group efforts generate positive feelings, which in turn lead to improved social interactions.

From this brief description of cooperative learning, evidence clearly points to both academic and social benefits in grouping children for instruction. Limited information exists, however, on what benefits accrue when mildly handicapped learners and their nonhandicapped peers work together to solve problems at a microcomputer.

\section{Variations in Group Structure and Microcomputer Effects}

Researchers from Project TEECh (Lieber \& Semmel, 1986) compared the microcomputer performance of children as a function of instructional group size and configuration. The research focused on effects of these contexts on academic and social outcomes for mildly handicapped learners. Participants in the study were 20 learning handicapped and 20 nonhandicapped boys from the upper elementary grades, who used a mathematics problem-solving software 
program entitled Teasers by Tobbs (O'Brien, 1984). The program requires that students solve addition problems to complete a $2 \times 2$ matrix. At the simplest level pupils solve for a sum: $a+b=$ ?. At the intermediate levels they are required to find a missing addend: $a+?=\mathrm{c}$. At the most difficult level the matrix takes the form of an open equation: $?+?=$ ?

Each participant worked at the computer for 4 weeks under three different group configurations each week: (a) individually, (b) with a handicapped partner, and (c) with a nonhandicapped partner. Time at the computer was held constant; each computer session lasted 10 minutes. Therefore, children working alone at the computer had 10 minutes to perform the problem-solving task; children working with a partner shared the computer for the 10-minute session.

\section{Math Problem-Solving and the Microcomputer Task}

Academic performance was gauged using formative and summative measures. One formative measure was number of problems attempted on the computer, which was used as a proxy measure for task engagement. Learners were found to perform a similar number of problems per minute whether they worked by themselves or with a partner performing alternate problems. Inspection of the data revealed that learning handicapped students were most highly engaged when paired with a nonhandicapped partner but nonhandicapped children worked most efficiently alone.

Results from both computer and paper-and-pencil performance showed overall that learning handicapped and nonhandicapped children performed equally well regardless of whether they worked alone or with a peer partner. This finding is particularly important to note because children working with a partner had half the actual contact with the computer as children working alone.

Lieber and Semmel (1986) reported data indicating that learning handicapped children may have performed optimally when they were paired with nonhandicapped partners. For example, on the paper-and-pencil task at the most difficult level, learning handicapped children averaged 6.89 problems correct (of 12) following the computer session in which they worked alone and 8.26 problems correct following the computer session in which they worked with a nonhandicapped partner. On the computer task at the most difficult level, the learning handicapped children correctly solved $49 \%$ of the problems that they attempted when they worked alone and $63 \%$ when they worked with a nonhandicapped partner.

\section{Social Processes During Microcomputer Sessions}

In addition to the academic benefits that accrued when children were grouped for instruction, Lieber and Semmel
(1986) reported social benefits. In general, when children worked together at the microcomputer, most conversation was specific to the task. In fact, the proportion of off-task statements ranged from only $3 \%$ to $7 \%$ across dyads. A similarly high level of attention to task for handicapped children using computers has been observed in other investigations (Berthold \& Sachs, 1974; Carman \& Kosberg, 1982; Cosden et al., in press).

When learning handicapped children were paired with nonhandicapped children, the role of "teacher" was attributed mainly to the nonhandicapped partner. In this configuration learning handicapped children made more requests for information and solved more problems out loud. Further, the nonhandicapped children made more management comments when paired with a learning handicapped partner. Management comments were made both to regulate the general behavior of the learning handicapped child and to make pacing comments related to the task. Lieber and Semmel (1986) described the tone within the dyads as task-oriented, since most of the conversation related to problem solving or to the computer. When evaluative comments did occur, the majority of them pertained to the task rather than to the children themselves. Self-evaluation statements were largely positive. Although peer-evaluation statements were largely negative, they occurred infrequently.

Apart from the task-related conversation, most communication that occurred within dyads was related to the computer and to the software program's graphics. Even in dyads in which children solved problems independently, they communicated about the graphics. The combination of cooperative activity, in which the efforts of one child were linked to the efforts of the partner, and the enthusiasm generated by the computer program appeared to create dyads in which the tone was generally positive.

In summary, the Lieber and Semmel (1986) study suggested that a pair of children working together at the microcomputer to solve mathematics problems is a beneficial configuration. Positive academic as well as social outcomes accrue.

\section{Problem Solving in Cooperative and Didactic Groups}

The strategy of grouping for instruction and its effects on problem-solving behavior of mildly handicapped children also was investigated by Riel (1983), using a different paradigm. She used several microcomputer games designed to improve numerical estimation, auditory perception, and logical inference to compare the linguistic performance, social skills, and problem-solving strategies of eight nonhandicapped and eight dysphasic children between 8 and 12 years old. Riel defined dysphasic children as those with a "testing profile which demonstrated a language problem or 
delay that was disproportionate with their other skills" (pp. 1-2). The students worked in homogenous pairs on the computer games in both cooperative and didactic sessions.

Riel found that all students enjoyed playing the games and interacting with the computer; they understood the procedures required and generally followed the instructions. The dysphasic students were similar to the nonhandicapped students in average number of words they used and average length of communication units used. Both groups were equally likely to ignore questions from the partners as to answer them correctly.

Nevertheless, the groups differed considerably. In the didactic situation the dysphasic children spent less time than the nonhandicapped tutors providing their partners with information about how to play the game. In the cooperative situation the groups divided tasks differently: The dysphasic pairs took turns playing the game while the normally achieving pairs were more likely to divide up the tasks and work jointly. The children also solved problems differently: Dysphasic students were highly dependent on adults; they turned to an adult first and rarely requested help either from the computer or from their partner while the nonhandicapped students turned first to the computer, then to the peer, and finally to an adult. Dysphasic children also frequently began the games without instruction and did not move to an easier level when the game they were playing was too difficult. These behaviors were infrequent for nonhandicapped children.

In a second study, Riel (1983) attempted to remediate some of the difficulties of the dysphasic children. She designed a training paradigm in which the computer was used to demonstrate steps that the student could use to frame the problem efficiently. The problem-framing structure then was withdrawn systematically when the child demonstrated ability to perform the problem-solving skills alone. Two transfer tasks then were used to determine the effect of the training study: teaching the game to a younger student, and playing a new game.

Following the training, the dysphasic children moved in the direction of the nonhandicapped students in a number of ways: (a) in problem solving they chose game levels that were more appropriate for their skills; (b) numerically they increased their skills in counting, in numerical comparisons, and in making number-line midpoint assessments; (c) socially the individual, competitive orientation to game playing exhibited in the first study was replaced by more cooperation; and (d) linguistically, the dysphasic students who participated in the training study spent more time in teaching and increased the number of words they used per communication unit.

The importance of training children to provide appropriate instruction was evident in the studies of both Lieber and
Semmel (1986) and Riel (1983). Lieber and Semmel found that extensive instructional activity occurred within the dyads but that teaching behavior was not associated with improved performance. Most of the teaching that occurred took the form of providing answers to questions rather than responding with an explanation of how to do the task. Receiving only an answer apparently did not give learners enough information to solve the problems for themselves.

In contrast, the dysphasic students in Riel's second study received training in problem-framing strategies delivered through a computer program. They were able to use this minimal training to more effectively teach game-playing behavior to younger partners. Most commercial software programs, however, do not have the capability to provide that type of assistance to the learner. For example, the commercial program (O'Brien, 1984) used by Lieber and Semmel provided help if requested, but this help was in the form of a correct answer. The computer help was similar to that provided by many partners and was similarly ineffective in improving performance on the paper-and-pencil task. Clearly, further investigation is required to determine if training is a necessary link to effective problem solving for handicapped learners.

Riel concluded that the micromputer provided a valuable educational context in several regards. She found that computers were motivating; that children were drawn into the game worlds that were created; computers were useful in providing an environment in which children with varying ability levels could interact in a beneficial way; and computers encouraged rather than inhibited interaction.

In a conclusion similar to that drawn by Lieber and Semmel (1986), Riel suggested that when children work together at the computer, pairing a handicapped child with a nonhandicapped child is most effective. When children with language difficulties were grouped together, they were continually exposed to deviant language. In fact, Riel found similar errors occurring in the speech of different children. Similarly, Lieber and Semmel found that when learning handicapped children were grouped in homogeneous dyads, they shared misinformation about how to solve particular matrices. Those difficulties were eliminated when learning handicapped children were paired with competent nonhandicapped partners. Additionally, Riel argued that the frequently demonstrated dependence of mildly handicapped childen on adult help (see Seligman, 1975, for a discussion of learned helplessness) can be attenuated by having a more competent peer available for consultation.

We conclude that substantial empirical evidence exists, based on the studies reviewed, that grouping children to work together on problem-solving activities leads to effective academic and social outcomes. Academic performance is facilitated for handicapped learners when they work with 
a partner rather than alone. Training in group instructional behavior likely will maximize outcomes. We need further investigation, however, to determine how larger group sizes affect performance. One study (Cox \& Berger, 1985), using normally achieving children, found a curvilinear relationship between group size and correct problem solving: Individuals solved significantly fewer problems than did groups, but groups of two or three tended to solve more problems with greater consistency than did teams of five. Moreover, groups working around a microcomputer have space limitations that do not affect non-computer groups.

In considering optimum group size, we must take into account that the group benefits from several points of view but that interest in the task is facilitated when each student has access to the computer. In addition, to have children perform problem-solving tasks in cooperative groups at the computer clearly is beneficial socially. When children work in groups, helpfulness (with its concomitant link to social acceptance) is shown, engagement remains high because children keep each other on-task, and task-related discussion occurs. Those experiences are unavailable to students who work alone at the computer.

\section{IMPLICATIONS FOR CONSTRUCTING EFFECTIVE MICROEDUCATIONAL ENVIRONMENTS}

At the outset we briefly alluded to a model for guiding research directed at determining the effects of microcomputer applications with mildly handicapped children in the schools. The model focuses, at the classroom level, on analysis and development of variable clusters constituting what M. Semmel et al. (1983) have referred to as MicroEducational Environments. To understand the effects of microcomputer applications in the schools, we assert that to answer important impact questions using simplistic comparative designs is unproductive. The configurations of hardware, software, user, peer group, and teacher characteristics that interact to present unique MEEs must be studied. The ultimate task is to identify MEEs that maximize specific instructional objectives for mildly handicapped learners. This approach is consistent with a framework developed by Winkler, Shavelson, Stasz, Robyn and Feibel (1985) for evaluating the pedagogically sound use of microcomputers. One measure of soundness provided by the Winkler et al. framework is the achievement of teachers' instructional goals, which may be academic, motivational, or social.

Use of an unembellished drill-and-practice mathematics program meets teachers' goals both for increasing rapid, correct performance and for maintaining task motivation. Its use leads to automaticity in children who are distracted easily by extraneous auditory and visual elements contained within arcade-like drill-and-practice programs. Students also are highly motivated to perform the tasks presented by the Plain Vanilla (Christensen, 1985) software program, as evidenced by their involvement and persistence. These tasks, which stress automaticity, have no requirements for discussion with a peer. This task probably is most efficiently accomplished alone; thus, it may not be the best choice to promote social goals. It must remain an empirical question that has not as yet been studied.

We propose that working together at the computer in a problem-solving task or game facilitates social goals that are particularly crucial for handicapped children who, as a group, are not well-accepted by their nonhandicapped peers (Bruininks, 1978; Bryan, 1974). Although teachers in mainstream classrooms may have a tendency to group handicapped children together, work emanating from Project TEECh and elsewhere indicates that benefits accrue when handicapped children work together with their nonhandicapped peers.

When children are grouped to apply higher order cognitive skills, teachers' goals for academic progress are accomplished as well. Having another child present allows questions to be answered and hypotheses about the most effective strategy for problem solving to be discussed. Learning within a group appears to be effective when material is in the acquisition stage.

Although we are witnessing a remarkable rate of growth in acquisition of technology in schools, relatively few computers currently are available when compared to instructional demands. Student use of microcomputers in elementary schools is curtailed by limited access and time allocation. Hence, teachers are required to use these limited resources in the most efficient and effective manner.

The issue of effectiveness is complex, but it can be approached as a joint problem for teachers and researchers. Evidence presented in this article, drawn from the empirical literature and extensive study by the Project TEECh research teams, suggests that teachers' goals are more likely to be achieved when specified software characteristics and grouping configurations are selected or developed to achieve instructional objectives for learners with specified attributes. The notions of person-by-environment fit (Hunt, 1975) and aptitude X treatment interaction (Cronbach \& Snow, 1977) are instructional strategies well worth pursuing in the context of the microcomputer revolution in the schools.

\section{REFERENCES}

Armstrong, B., Johnson, D. W., \& Balow, B. (1981). Effects of cooperative vs. individualistic learning experiences on interpersonal attraction between learning-disabled and normal-progress elementary school students. Contemporary Educational Psychology, 6, 102-109. 
Ballard, M., Corman, L., Gottlieb, J., \& Kaufman, M. J. (1977). Improving the social status of mainstreamed retarded children. Journal of Educational Psychology, 69(5), 605-611.

Becker, H. J. (1983, April.) School uses of microcomputers (Issue No. 1). Baltimore, MD: Johns Hopkins University, Center for Social Organization of Schools.

Becker, H. J. (1985, July). The second national U.S. school uses of microcomputers survey. Paper presented at the World Conference on Computers in Education, Norfolk, VA.

Berthold, H. C., \& Sachs, R. H. (1974). Education of the minimally brain damaged child by computer and by teacher. Programmed Learning \& Educational Technology, 11(3).

Bruininks, V. L. (1978). Peer status and personality characteristics of LD and nondisabled students. Journal of Learning Disabilities, 11(8), 484489.

Bryan, T. (1974). Peer popularity of learning disabled children. Journal of Learning Disabilities, 7, 621-625.

Carman, G. O., \& Kosberg, B. (1982). Educational technology research: Computer technology and the education of emotionally handicapped children. Educational Technology, 22(2), 26-30.

Chaffin, J., \& Maxwell, B. (1982). Arcademic skill builders in math: Teacher's manual. Allen, TX: Developmental Learning Materials.

Chaffin, J. D., Maxwell, B., \& Thompson, B. (1982). ARC-ED curriculum: The application of video game formats to educational software. Exceptional Children, 49(2), 173-178.

Christensen, C. A. (1985). Plain vanilla: A computerized drill and practice program for single digit addition [Computer program]. Santa Barbara: University of Califormia, Project TEECh.

Christensen, C. A., \& Gerber, M. M. (1986, March). Effects of game format in computerized drill and practice on development of automaticity in single digit addition for learning disabled students (Tech. Rep. No. 29). Santa Barbara: University of California, Project TEECh.

Clark, R. E. (1983). Reconsidering research on learning from media. Review of Educational Research, 53(4), 445-459.

Cooper, L., Johnson, D. W., Johnson, R., \& Wilderson, F. (1980). The effects of cooperative, competitive, and individualistic experiences on interpersonal attraction among heterogeneous peers. Journal of Social Psychology, 111, 243-252.

Cosden, M. A., Gerber, M. M., Semmel, D. S., Goldman, S. R., \& Semmel, M. I. (in press). Micro-educational environments and microcomputer use for special day class, resource room, and mainstream handicapped and nonhandicapped students. Exceptional Children.

Cosden, M. A., Pearl, R., \& Bryan, T. H. (1985). The effects of cooperative and individual goal structures on learning disabled and nondisabled students. Exceptional Children, 52(2), 103-114.

Cox, D. A., \& Berger, C. F. (1985). The importance of group size in the use of problem-solving skills on a microcomputer. Journal of Educational Computing Research, 1(4), 459-468.

Cronbach, L. J., \& Snow, R. E. (1977). Aptitudes and instructional methods: A handbook for research on interactions. New York: Irvington.

Dickson, W. P., \& Vereen, M. A. (1983). Two students at one microcomputer. Theory into Practice, 22(4), 296-300.

Edwards, J., Norton, S., Taylor, S., Weiss, M., \& Dusseldorp, R. (1975). How effective is CAI? A review of the research. Educational Leadership, 33, 147-153.

Everhart, R. B., McCarthy, E., \& Simpson, E. (1985). Learning handicapped students and microcomputers: A case study of two elementary schools (Tech. Rep. No. 17). Santa Barbara: University of California, Project TEECh.

Gagne, R. M. (1983). Some issues in the psychology of mathematics instruction. Journal for Research in Mathematics Instruction, 14, 7-18.

Garson, J. W. (1983). The case against multiple choice. In D. O. Harper \& J. H. Stewart (Eds.). Run: Computer education (pp. 120-126). Monterey, CA: Brooks/Cole.

Hallahan, D. P., \& Reeves, R. E. (1980). Selective attention and distractibility. In B. K. Keogh (Ed.), Advances in special education: Vol. I, Basic construction and theoretical orientations (pp. 141-181). Greenwich, CT: JAI Press.

Hofmeister, A. M. (1984). The special educator in the information age. Peabody Journal of Education, 62(1), 5-21.
Hunt, D. E. (1975). Person-environment interaction: A challenge found wanting before it was tried. Review of Educational Research, 45, 209230.

Johnson, D. W., \& Johnson, R. T. (1980). Integrating handicapped students into the mainstream. Exceptional Children, 47(2), 90-98.

Johnson, R. T., \& Johnson, D. W. (1982). Effects of cooperative and competitive learning experiences on interpersonal attraction between handicapped and nonhandicapped students. Journal of Social Psychology, 116, 211-219.

Johnson, R., Rynders, J., Johnson, D. W., Schmidt, B., \& Haider, S. (1979). Interaction between handicapped and nonhandicapped teenagers as a function of situational goal structuring: Implications for mainstreaming. American Educational Research Journal, 16(2), 161167.

Kleiman, G., Humphery, M., \& Lindsay, P. H. (1983). Microcomputers and hyperactive children. In D. O. Harper \& J. H. Steward (Eds.), Run: Computer education (pp. 227-228). Monterey, CA: Brooks/Cole.

Lepper, M. R. (1985). Microcomputers in education: Motivational and social issues. American Psychologist, 40(1), 1-18.

Lesgold, A. M. (1983). A rationale for computer-based reading instruction. In A. C. Wilkenson (Ed.), Classroom computers and cognitive science (pp. 167-181). New York: Academic Press.

Lieber, J., \& Semmel, M. I. (1985). Effectiveness of computer application to instruction with mildly handicapped learners: A review. Remedial \& Special Education, 6(5), 5-12.

Lieber, J., \& Semmel, M. I. (1986, March). The effect of group size and configuration on social and performance behaviors of mildly handicapped using microcomputers (Tech Rep. No. 22). Santa Barbara: University of California, Project TEECh.

Littlejohn, T. D., Ross, R. P., \& Gump, P. V. (1984, April). Using computers in elementary schools: Implementation issues. Paper presented at American Educational Research Association, New Orleans.

McDermott, P. A., \& Watkins, M. W. (1983). Computerized vs. conventional remedial instruction for learning-disabled pupils. Journal of Special Education, 17(1), 81-88.

Madden, N. A., \& Slavin, R. E. (1983). Effects of cooperative learning on the social acceptance of mainstreamed academically handicapped students. Journal of Special Education, 17(2), 171-182.

Malone, T. W. (1981). Toward a theory of intrinsically motivating instruction. Cognitive Science, 4, 333-369.

Martino, L., \& Johnson, D. W. (1979). Cooperative and individualistic experiences among disabled and normal children. Journal of Social Psychology, 107, 177-183.

O'Brien, T. C. (1984). Teasers by Tobbs: Puzzles and problem solving [Computer program and computer program manual]. Pleasantville, NY: Sunburst Communications.

Riel, M. M. (1983). Investigating the system of development: The skills and abilities of dysphasic children (CHIP Report No. 115). San Diego: University of California, Center for Human Information Processing.

Russell, S. J. (1983, October). LOGO in special education. Classroom Computer Learning, pp. 34-39.

Seligman, M. E. (1975). Helplessness: On depression, development, and death. San Francisco: W. H. Freeman.

Semmel, D. S., Goldman, S. R., Gerber, M. M., Cosden, M. A., \& Semmel, M. I. (1985). Survey of special education and mainstream teachers' access to and use of microcomputers with mildly handicapped students (Tech. Rep. No. 9.0). Santa Barbara: University of California, Project TEECh.

Semmel, M. I., Cosden, M. A., Semmel, D. S., \& Kelemen, E. (1984). Training special education personnel for effective use of microcomputer technology: Critical needs and directions. Special Services in the Schools, I(1), 63-82.

Semmel, M. I., Semmel, D. S., Cosden, M. A., Gerber, M. M., \& Goldman, S. R. (1983). An analysis and development of naturalistic and experimentally constructed microeducational environments for mildly handicapped learners. Santa Barbara: University of California, Graduate School of Education.

Slavin, R. E. (1983). Cooperative learning. New York: Longman.

Slavin, R. E., Madden, N. A., \& Leavey, M. (1984). Effects of cooperative learning and individualized instruction on mainstreamed students. $E x$ ceptional Children, 50(5), 434-443. 
Smith, K., Johnson, D. W., \& Johnson, R. (1982). Effects of cooperative and individualistic instruction on the achievement of handicapped, regular and gifted students. Journal of Social Psychology, 116, 277-283.

Torgesen, J. K. (1984). Instructional uses of microcomputers with elementary aged mildly handicapped children. Special Services in the Schools, $1(1), 37-48$.

Turkel, S. B., \& Podell, D. M. (1984, Summer). Computer-assisted learning for mildly handicapped students. Teaching Exceptional Children, 16(4), 258-262.

Varnhagen, S., \& Gerber, M. M. (1984). Use of microcomputers for spelling assessment: Reasons to be cautious. Learning Disability Quarterly, 7, 266-270.

Visonhaler, J. F., \& Bass, R. K. (1972). A summary of ten major studies on CAI drill and practice. Educational Technology, 12, 29-32.
Watkins, M. W., \& Webb, C. (1981). Computer assisted instruction with learning disabled students. Educational Computer Magazine, 1(3), 2427.

Webb, N. M. (1982). Student interaction and learning in small groups. Review of Educational Research, 52(3), 421-445.

Winkler, J. D., Shavelson, R. J., Stasz, C., Robyn, A. E., \& Feibel, W. (1985). Pedagogically sound use of microcomputers in classroom instruction. Journal of Educational Computing Research, 1(3), 285-293.

This paper was supported in part by a grant from the U.S. Department of Education, Office of Special Education and Rehabilitation Services, G0083-02860, to Project TEECh, Technology Effectiveness with Exceptional Children.

\section{INDEX $\bullet \quad$ VOLUME 18}

\section{Author Index}

Alpert, Cathy L. (April 1986)

Brantlinger, Ellen A. (September 1985)

Braxdale, Catherine Trefz (December 1985)

Colson, Steven E. (December 1985)

Esquivel, Giselle B. (November 1985)

Gerber, Michael M. (February 1986)

Guskin, Samuel L. (September 1985)

Kaiser, Ann P. (April 1986)

Lieber, Joan A. (May 1986)

McCarthy, Pat (January 1986)

Moon, M. Sherril (January 1986)

Robinson, Suzanne, M. (December 1985)

Semmel, Melvyn I. (May 1986)

Skrtic, Thomas M. (March 1986)

Taylor, Ronald L. (October 1985)

Warren, Steven F. (April 1986)

Wehman, Paul (January 1986)

Yoshida, Roland K. (November 1985)

\section{Chronological Index of Titles}

Implications of Social and Cultural Differences for Special Education with Specific Recommendations (September 1985)

Measuring Adaptive Behavior: Issues and Instruments (October 1985)

Special Education for Language Minority Students (November 1985)

Preparing Dysfunctional Learners to Enter Junior High School: A Transitional Curriculum (December 1985)

Transition from School to Adulthood for Youth with Severe Handicaps (January 1986)

Cognitive-Behavioral Training in the Curriculum: Time, Slow Learners, and Basic Skills (February 1986)

The Crisis in Special Education Knowledge: A Perspective on Perspective (March 1986)

An Optimal Learning Environment for Infants and Toddlers with Severe Handicaps (April 1986)

Computer Applications in Instruction (May 1986) 